\section{7. 大学における体市・スポーツの社会学的研究} 一とくに正趿部所屈者の卒菜後の動问についてー 九州工業大学○村 上 一 佐賀大学井上正薏 活水女子短大 久 保 俊 兼 九州大学岡部弘道 大分大学植村典昭

1. 目的 学生時代の体有・スポーツ活動が，どのよ うな動機で始められ，その活動内容抢よび実態はどらで あつたか，またそれがその後の生活，および特に身体活 動に如何なる影響を扣よぼしながら現在に至つている か. な技先彗として今日の大学の体育・スポーツ活動に ついて如何なる意見や要望を持ち，これをどのように評 価し旦つ価値つけているかなどについて調査し，その結 果を今後の大学の体育・スポーッの在り方を検討するた めの資料としょうとしたものである.

2. 方法 質問紙法により昭和 41 年 11 月より 12 月に 至る 2 力月間に，九州地区の大学卒業生にたいして国立 -教育・私立・女子の大学別, 拉よび種目別, 年代別を 考慮して所属者, 非所属者 2,026 人について調查した.

3. 結果 卒業後もスポーツを続けている者は所属者 で70.7\%と継続率は高く, 非所属者との間にかなりの差
がある.な打所属者の経験種目の継続状態では，テニ ス，バレーボール，剣道のような継続型と、ラクビー, 柔道の上うに他種目へと变る移行型の二つの傾向が顕著 にみられた，媈動部活動が現在の生活にプラスしたと答 えた者は80\%以上で圧倒的に多かつた. 内容的には「身 体が丈夫になつた」「協調性ができた」「現在であスポ ーツを楽しむことができる」などが目立つている，大学 教育とスポーツ関係でみると，学問中心の生活の中にる 適当なスポーツ活動は必要であると認めて扣り，しかも 非所属者の方がより重視している．現在の学生スポーツ 活動にたいしては「スポーツ活動の目的は人間形成にあ るべきだ」「多くの者が楽しめ参加できるスポーツ」で なければならない，そのためには「学問との両立」は必 要条件であり「学生スポーツのプロ化の如き現象はあく までも排除し」「施設の㹡充と経娍援助」が急務である と，かなり批判的で強い要望があることがわかる．「シ ゴキ」については馬鹿げた現象だと否定する空気は強い が，プロ化汪どの否定の強さではなく、「根性づくりの ためにはある程度やむを得ないのではないか」という， やや肯定的な意見もかなりある.特に私立の所属者では $52.6 \%$ が肯定的であるのは注目すべきである.
68. クーデンホーフ・カレルギーの体高権について（そ の2)

\section{-Gentlemanideal と体市一}

奈良工業高等専門学校○中和田武 奈良教育大学近藤英男

さきにクーデンホーフ・カレルギーの体育観について 概観したが，今回は彼の哲学思想としての超倫理につい て述べそれれ背景とした理想的人間像と体育の連関に ついて考察を試みた。

超倫理とは宗教的なものではなく，倫理と美学の総合 したものである.これはカロカガテイアの現代化ともい うべきもので，健全な自然本能を基盤とした人間の美学 である.

超倫理的な人間の最高のタイプは，偉大さ，強さ，自 由，調和に基つく親切な人であり，この人間の親切心を 通じて最高の美, 即ちカロカガテイフに到達しらると考 えている.このような最高の理念から両性に異なる理想 像をかかげ，男子は勇敢で力を維持し，女性は母性舜に めさめ美を保つべきであり，男性の精神生活の基璴俚 Gentlemanideal, 女性のそれは Lady の理想であつて， 今日的な Gentleman と Lady を両性の理想像として
あげている.そしてこの両性の理想像は，自然界の同価 值の両檑性をなし，その統合されたものだけが彼のいら 美の頂点に達するのである.

このような理想的人間の育成は，超倫理教育によつて 達成しらるものとし，その教育目槚は肉体，性格，精神 の健康，訓練，美容，節制である. 少年は強く，少女は 美しくなるように教育すべきであり，男子は樍杫的英雄 精神，女子は消梗的英雄精神の強さをむつべき坑として いる．彼は体育を，人間育成に括ける順序の第一にあ げ，次いで人格垬成，知的教育としている．即ち教育は 体有から始めるべきであり，少年はスポーツを，少女は ダンスをるつて始めるべきであるとし，スポーツを通し て男子の求める美は，力，拔術美，フェアプレーの精神 など即ち Gentlemanideal であつて，ダンスを通して女 子の求める美は創造された芸術美, 即ち Lady の理想 である.さらにわれわれが為的な道徳制度によって失 われた人間の自然本能，道徳，精神を本来の姿にもどす ためにも体育は不可欠であると述べている.

体育を通しての人間形成と，体育に上る新しい精神文 化の創造発展を志向した点に，彼の思想の今日的意義を みることができるのである. 